sented the Association on the Geophysical Committee of the Royal Astronomical Society, and contributed a number of valuable papers to the Journal of the Association.

In 1884 Hollis was elected a fellow of the Royal Astronomical Society, and served on the Council from 1909 until 1911. A number of papers appeared under his name in the Monthly Notices and the Memoirs; the last of theso was in the Monthly Notices 79, 36 (1918), in which he discussed the magnitudes of Nova Aquila, deduced from the photographs which had been taken at the Royal Observatory, Greenwich. He edited the Observatory magazine from 1893 until 1912, and for many years was astronomical correspondent to The Times, to which he contributed the well-known article, "Stars of the Month". In 1910 his work, "Chats on Astronomy", was published. This was written in a popular style and was specially useful to beginners interested in astronomy.

Hollis maintained his interest in astronomy to the end, in spito of his physical disability. Ho seldom missed any astronomical meetings, and his mental faculties seemed unimpaired.

In 1882 he married Clara Susanna Clark, who predeceased him in 1932. Two sons and a daughter survive him.

\section{Prof. L. Lévy-Bruhl}

We regret to record the death of Prof. I. LevyBruhl, the distinguished French philosopher and ethnologist, which took place in Paris on March 12 last at the age of eighty-one years.

Lucien Lévy-Bruhl was born on April 10, 1857. For long he had held a foremost place in the develop. ment in France of philosophical and sociological studies. Ho was appointed professor of philosophy in the Sorbonne in 1899 and occupied that chair until 1927, when on his retirement he was appointed honorary professor. He was elected a member of the Academy in 1917. Ho edited the Revue philosophique for many years. During 1927-30 he was president of the Institut française d'Anthropologie, of which he was one of the founders and a constant and enthusiastic attendant at its meetings so far as the calls of a busy life allowed. He had travelled widely, and had made the voyage round the world. He delivered courses of lectures in the universities of many countries outside France, including Egypt and both North and South America.

Although Prof. Lévy-Bruhl was the author of a number of profound works on philosophical topics, ho was best known to a wide public in both France and England for his studies of primitive and 'savago' mentality, soveral of which appeared in English translation, whilo in France they served to introduce the psychological aspects of social anthropology to a wider circlo than is usually attracted by scientific studies. In this field his principal or best lknown works are "Fonctions mentales dans les Societes inférieures" (1910), "Mentalité primitive" (1922), and "Surnaturel et la Nature" (1930). In these and others of a kindred character he developed his theories of primitive mentality as belonging to a mystic and prological stage of thought in a graceful and lucid style and with the support of a full documentation of facts.

\section{Mr. Clifford Chaffer, O.B.E.}

Mir. Clifford Chaffer, superintendent of the Admiralty Research Laboratory, died suddenly on June 26 at his home at Weybridge, Surrey, at the early age of fifty-four years.

Mr. Chaffer was born on October 25, 1881, at Morley, Yorkshire, and, after going to the Wheelwright Grammar School, Dowsbury, became a scholar of Peterhouse, Cambridge, where he remained from 1903 until 1907. He was 18th wrangler in 1906 and took the National Science Tripos in 1907. On leaving the University ho held mathematical masterships for a number of years.

In $1916 \mathrm{Mr}$. Chaffer was appointed a temporary Instructor Lieutenant in the Royal Navy, and after service at sea he was posted to the Admiralty Compass Department. On demobilization in 1920 he accepted an appointment on the civil staff of the Compass Department where he continued to serve until 1936 when he was transferred to the headquarters staff of the Department of Scientific Iiescarch and Experiment at the Admiralty.

He was appointed to the Admiralty Research Laboratory as superintendent in 1937 and in this position his clear judgment, power of recognizing tho essential features of the problems with which he was called upon to deal, and his ability to inspire the staffs with his personal keenness and single-minded devotion to duty were of the greatest value in a time of unusual stress.

\section{Baron Joji Sakurai}

Dr. Marie Stopes writes: "All that Prof. Donnan says in the first paragraph (Nature, Aug. 5, p. 234) of his obituary notice of Japan's greatest scientist I should like to endorse from personal experience while an honorary member of the professor's common room in the Imperial University, Tokyo. However, no obituary would be complete without mention of his spiritual and literary sensibilities. Theso were partly revealed by his interest and proficiency in the profound medieval religious plays 'Tho Nö' which he and $I$ translated togother into English and published under the title 'Plays of Old Japan'. The then Japaneso Ambassador, Baron Kato, wrote that they 'placed Western students of Japanese art and literature under a debt of gratitude'. Prof. Sakurai, who was a most faithful friend, was in Great Britain for the Coronation of King George VI, and I had the privilege of viewing it with him. He was one of the few scientists who made one revere him".

We regret to announce the death of Prof. E. Westermarck, formerly professor of sociology in the University of London, aged seventy-seven years. 